\title{
2C: Pathophysiological aspects of $H$. pylori infections
}

\section{C:01 HELICOBACTER PYLORI, HYPERGASTRINEMIA AND OMEPRAZOLE THERAPY}

B.E. Schenk ${ }^{1}$, E.J. Kuipers ${ }^{1}$, E.C. Klinkenberg-Knol ${ }^{1}$, E. Bloemena ${ }^{1}$, G.F. Nelis ${ }^{2}$, H.P.M. Festen ${ }^{3}$, C.B.H.W. Lamers ${ }^{4}$, S.G.M. Meuwissen ${ }^{1}$ ${ }^{1}$ Free Univ. Hospital, Amsterdam; ${ }^{2}$ Sophia Hospital, Zwolle; ${ }^{3}$ Groot Ziekengasthuis, Den Bosch; ${ }^{4}$ Academic Hospital, Leiden, The Netherlands Infection with Helicobacter pylori $(H p)$ and treatment with profound acid suppressive drugs are two unrelated conditions associated with mild hypergastrinemia (HG). During treatment with omeprazole, some patients however develop severe HG (> $400 \mathrm{ng} /)$ and ECL hyperplasia. The cause of these extreme gastrin levels is unknown. One hypothesis is that they are associated with $H p$ infection and atrophic gastritis. Other explanations include vagal nerve dysfunction and delayed gastric emptying. We studied 26 GERD patients (pts) treated with maintenance PPI; 13 with severe hypergastrinemia ( $8 \mathrm{M}$, mean age: $66 \mathrm{yrs}$, range $50-75)$ and 13 controls (10 M, age: 60 yrs, 49-72). Mean baseline serum gastrin \pm SEM was 1381 \pm 236 vs. $186 \pm 32 \mathrm{ng} / \mathrm{l}(\mathrm{p}<0.001$ ). Pretreatment gastrin levels were normal $(<100 \mathrm{ng} / 1)$ in all 26 subjects. Methods: $H p$ infection was assessed by serology and histology. Delayed gastric emptying was determined by endoscopical scoring of food remnants 12 hours after a standard meal. All subjects underwent a meal-stimulated gastrin test (SGT). Vagal nerve function was assessed by a pancreas polypeptide test (PPT) in HG pts. Results: $9 / 13$ HG pts vs. $2 / 13$ controls were infected with $H p(p<0.02$, Mann Whitney U-test). Atrophy of corpus occurred more often in HG's $(8 / 13)$ than in controls $(2 / 13 ; \mathrm{p}=0.05)$ and was in $9 / 10$ cases associated with $H p$ infection $(p<0.05)$. Food retention was observed in $2 / 12$ HG pts (vs. $0 / 12 ; p=$ n.s.) PPT response showed no difference between HG pts $(\triangle \mathrm{PP}: 115 \mathrm{pmol} / \mathrm{l}(\mathrm{n}=9)$ vs. controls $140(\mathrm{n}=8)(\mathrm{p}=0.09)$. Response on SGT was, although within normal limits in both groups, diminished in HG pts ( $\triangle$ Mean \pm SEM: $98 \pm 16 \%$ vs. $187 \pm 26 \%, p=0.01$ ). Conclusion: Development of hypergastrinemia during omeprazole therapy is associated with $H p$ infection and induced atrophic gastritis. No correlation was found with stomach emptying or vagal nerve function as measured by the PPT. Antral G-cel response on SGT was diminished in the group with severe hypergastrinemia.

\section{C:02 INDUCIBLE NITRIC OXIDE (NO) SYNTHASE IN HELICOBACTER PYLORI (HP) ASSOCIATED GASTRITIS IN DUODENAL ULCER PATIENTS}

J. Stachura, J.W. Konturek, E. Karczewska, W. Domschke, S.J. Konturek. Inst Physiol \& Pathomorphol Univ Sch Med Krakow \& Dept Med B, Univ Muenster, FRG

Previous studies showed the presence of constitutive NO synthase (NOS) in gastric mucosa but no study was undertaken to identify inducible NOS (iNOS) in mucosa damage associated with Hp infection in men. The immunohistochemistry, which selectively stains iNOS has been used to detect the iNOS in the antral mucosa obtained by endoscopic biopsy from Hp positive $\left({ }^{14} \mathrm{C}\right.$-urea breath test, histology and culture) duodenal ulcer (DU) patients and in the Hp isolated from the culture of antral mucosa. These bacteria were checked that they are members of the group of Gramnegative, spirally curved micro-aerophylic, oxidase-positive rods. A sterile swab harvested all culture from previously prepared subculture plates. The density of bacteria suspended in saline was $\approx 10^{9} \mathrm{CFU}$ and $30 \mu \mathrm{l}$ of this suspension was smeared on glass and air dried. The immunoreactivity of iNOS was examined using primary antibody (Santa Cruz Biotechnology Inc, Santa Cruz, CA) diluted at 1:50. The reaction was completed with APAAP Dako kit (Dako, Copenhagen) using fast red as chromogen. The iNOS was found in the antral mucosa obtained during gastroscopy from 50 active DU patients who were Hp-positive (with ${ }^{14} \mathrm{C}$-urea breath test, CLO-test and culture). The iNOS was detected in histiocytic cells and in mucosal microvessel cells. The epithelial cells in the pits and glands were negative. The isolates from these DU patients were strongly stained by the antibody used in all tested samples. We conclude that $\mathrm{Hp}$ is capable of expressing iNOS and NO produced in excess in gastric mucosa by this enzyme may contribute to the pathogenesis of $\mathrm{Hp}$-associated gastritis.

\section{C:03 CagA STATUS INFLUENCES ACTIVITY AND EPITHELIAL INJURY BUT NOT THE PATTERN OF H. PYLORI GASTRITIS}

V.J. Warburton ${ }^{1}$, S. Everett ${ }^{2}$, N.P. Mapstone ${ }^{1}$, A.T.R. Axon ${ }^{2}$, P. Hawkey ' , M.F. Dixon ${ }^{1} .^{1}$ University of Leeds, Leeds General Infirmary, Leeds, UK; ${ }^{2}$ Centre for Digestive Diseases, Leeds General Infirmary, Leeds, UK

$H$. pylori strains which express the cagA gene are more likely to be associated with peptic ulcer disease. Ulcer disease is also associated with different patterns of $H$. pylori gastritis, therefore we examined the distribution of gastritis and the presence of the cagA gene in isolates from patients attending a dyspepsia clinic in the UK. Methods: $H$. pylori isolates from 140 patients were investigated to determine the prevalence of the cagA gene by PCR. A group of $28 \mathrm{cagA}$ negative (-) isolates were age/sex matched to 28 cagA positive ( + ) isolates. Histology from these cases was assessed "blind" by a single observer, scoring the following features from 0-3 for both antral and corpus biopsies: Chronic inflammation (Ci); Polymorphonuclear activity (Ac); Surface Epithelial Degeneration (SED); Atrophy (At); Intestinal Metaplasia (IM) and H. pylori colonisation density (Hp). The degree of antral predominance was assessed by subtracting corpus scores from antral scores for each patient. Results: The cagA prevalence in this group of patients was found to be $80 \%$. There was no difference in frequency of peptic ulceration between cagA+ (39\%) and cagA- (28\%) groups. The following mean scores were obtained for each gastritis feature in patients that harboured cagAt isolates and those with cagA- isolates.

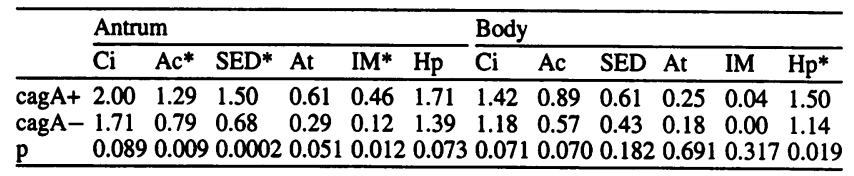

*Features for which grades were significantly different (Mann Whitney-U) between cagA+ and cagA- groups.

No significant difference was found for the distribution of gastritis between cagA+ and cagA- groups.

Conclusions: The cagA prevalence in this population was higher than reported in other populations. These findings support a role for cagA in determining the severity of epithelial injury and polymorph response. However, we found no evidence to indicate that this gene affects the distribution of $H$. pylori gastritis.

\section{C:04 HELICOBACTER PYLORI INFECTION IS ASSOCIATED WITH REDUCED SERUM FERRITIN LEVELS IN ADULTS}

S.J. Rosenstock ${ }^{1,2}$, N. Milman ${ }^{2}$, L.P. Andersen ${ }^{1}$, O. Bonnevie ', T. Jørgensen ${ }^{1,2}{ }^{1}$ The Copenhagen Hospital Corporation, University of Copenhagen, Denmark; ${ }^{2}$ The Glostrup Population Studies, University of Copenhagen, Denmark

Purpose: To examine the relationship between $H$. pylori infection status and serum ferritin in an adult population. Methods: A random sample of 3,589 Danes aged 30-60 years participated in a population survey in 1982-1983. Sera stored at $-20^{\circ} \mathrm{C}$ at study entry were thawed and analyzed in 1993. Sera from 2,770 participants were eligible for measurements of serum ferritin. Circulating IgG antibodies against $H$. pylori. IgG antibody levels were measured with an in-house ELISA assay. Cut-off points for seronegativity and seropositivity were set at $\leq 100$ ELISA units (Eu) and $\geq 400 \mathrm{Eu}$, respectively. Serum ferritin was measured with an immunoradiometric assay. Information on age, menopause, socio-economic status, blood-donation, medical history including peptic ulcer disease, ingestion of NSAID, and alcohol intake was ascertained from a validated questionnaire. Results: Serum ferritin values were significantly lower in IgG seropositive men and postmenopausal women than in uninfected individuals (men: 124 $\mu \mathrm{g} / \mathrm{lvs} .143 \mu \mathrm{g} / \mathrm{l}, p=0.023$, postmenopausal women: $64 \mu \mathrm{g} / \mathrm{l}$ vs. 80 $\mu \mathrm{g} /, p=0.012)$. A significant linear association $(p=0.0043)$ was found between $\log$ (seferritin) and IgG antibody levels. This association remained significant in multivariate analyses after adjustments were made for age, alcohol intake, and social status. Conclusion: Serum ferritin values are reduced in subjects with increased IgG antibody levels to $H$. pylori. It is suggested that $H$. pylori may affect iron metabolism in otherwise healthy individuals by increasing iron loss or impairing the uptake of iron. 


\section{C:05}

CURE OF H. PYLORI INFECTION DOES NOT AFFECT ACIDITY IN THE SPONTANEOUSLY SECRETING STOMACH OF DUODENAL ULCER PATIENTS

B. Tillenburg, U. Peitz, G. Börsch, M. Stolte, J. Labenz. Elisabeth Hospital Essen, Germany

Aim: The present study was designed to evaluate the long-term effect of curing $H$. pylori infection on the intragastric acidity in duodenal ulcer patients.

Methods: Eleven duodenal ulcer patients infected by $H$. pylori were studied. 24-hour $\mathrm{pH}$ recordings were performed before treatment of the infection as well as 4 weeks and 1 year after the cure. Glass electrodes were placed $5 \mathrm{~cm}$ below the cardia.

Results: Cure of $H$. pylori infection was associated with a marked improvement of antrum and corpus gastritis and a decrease of the fasting gastrin levels. The acidity in the spontaneously secreting stomach, however, remained unchanged: median gastric $\mathrm{pH}$ during 24 hours (before cure vs 4 weeks after cure vs 1 year after cure): 1.1 vs 1.2 vs $1.2, \mathrm{p}>0.3$, daytime: 1.0 vs 1.1 vs $1.1, \mathrm{p}>0.4$, postprandial: 1.4 vs 1.3 vs $1.3, \mathrm{p}=0.5$, night-time: 1.6 vs 1.0 vs $1.1, \mathrm{p}>0.1$; mean [H+] activity (24 hours): 88.4 vs 70.4 vs $79.0 \mathrm{~h} \times \mathrm{mmol} / \mathrm{l}, \mathrm{p}>0.45$ ).

Conclusions: Despite a decrease of the gastrin release and a decrease of the acid output (EIOmar et al, Gastroenterology 1995; 109: 681-91), the intragastric acidity remains unchanged after the cure of a $\mathrm{H}$. pylori infection in duodenal ulcer patients, suggesting that the net effect of the decreased acid output on the gastric $\mathrm{pH}$ is compensated by other mechanisms, e.g. the loss of neutralizing substances like ammonia generated by $\mathrm{H}$. pylori.

\section{C:06 EFFICACY OF OMEPRAZOLE ONE YEAR AFTER CURE OF $H$. PYLORI INFECTION IN DUODENAL ULCER PATIENTS}

J. Labenz, B. Tillenburg, U. Peitz, J.-P. Idström, E. Verdú, M. Stolte, G. Börsch, A.L. Blum. Elisabeth Hospital Essen and Klinikum Bayreuth, Germany; CHUV, Lausanne, Switzerland; Astra Hässle Mölndal, Sweden

Aim: The present study was designed to elucidate, whether the effect of curing $H$. pylori infection on the $\mathrm{pH}$ response to omeprazole is transient, persistent or increasing over time.

Methods: We studied 12 duodenal ulcer patients infected by $H$. pylori. Intragastric acidity was measured with glass electrodes placed $5 \mathrm{~cm}$ below the cardia on day 8 of a treatment with omeprazole $20 \mathrm{mg}$ (9:15 a.m.) before Helicobacter treatment, 4 to 6 weeks and 1 year after the cure.

Results: Cure of $H$. pylori infection resulted in a lowered $\mathrm{pH}$ during omeprazole treatment. This effect persists after one year. Median 24 hour gastric $\mathrm{pH}$ before treatment was 5.6, 4-6 weeks after cure it was $2.9(\mathrm{p}$ $=0.003)$, and 1 year after cure it remained unchanged $(\mathrm{pH} 2.5, \mathrm{p}=0.5)$. Accordingly, twice as much time was spent above $\mathrm{pH} 3$ and $\mathrm{pH} 4$ before treatment than 1 and 12 months after cure (percentage of time $\geq \mathrm{pH} 3$ : 82.7 vs 49.7 vs 43.1 ; percentage of time $\geq \mathrm{pH} \mathrm{4:} 72.7$ vs 38.3 vs 26.4). The severity of gastritis improves over time, while the fasting gastrin levels decreased rapidly and remained unchanged during the one-year follow-up.

Conclusions: In duodenal ulcer patients, cure of $H$. pylori infection resulted in a marked rapid and persistent decrease of the $\mathrm{pH}$ increasing effect of omeprazole. Therefore, $\mathrm{H}$. pylori is a determinant of the $\mathrm{pH}$ achieved in response to omeprazole treatment in duodenal ulcer patients.

\section{C:07 CURE OF H. PYLORI INFECTION DECREASES THE ANTISECRETORY EFFECT OF RANITIDINE IN DUODENAL ULCER PATIENTS}

B. Tillenburg, A.L. Blum, U. Peitz, E. Verdú, G. Börsch, M. Stolte, J. Labenz. Elisabeth Hospital Essen and Klinikum Bayreuth, Germany; CHUV Lausanne, Switzerland

Aim: We have recently shown that cure of a $H$. pylori infection in duodenal ulcer patients decreases the $\mathrm{pH}$-increasing effect of the proton pump inhibitor omeprazole. The present study was designed to test the hypothesis that cure of the infection weakens the effectiveness of ranitidine to a similar extent.

Methods: 18 duodenal ulcer patients infected by $H$. pylori were studied. We performed 24-hour $\mathrm{pH}$ recordings on day 8 of a treatment with ranitidine $300 \mathrm{mg}$ at 9:00 p.m. before and 4 to 6 weeks after the cure of the infection. An Ingold glass electrode was placed $5 \mathrm{~cm}$ below the cardia.

Results: Cure of the infection was associated with a marked improvement of the antrum and corpus gastritis and with a decrease of the fasting gastrin levels $(64.5$ vs $41.0 \mathrm{pg} / \mathrm{ml}, \mathrm{p}<0.0001)$. Cure of the infection did not affect the acidity during daytime (median gastric $\mathrm{pH}: 1.3$ vs $1.2, \mathrm{p}=$ 0.26 ) and after meals (median gastric $\mathrm{pH}: 1.4$ vs $1.2, \mathrm{p}=0.18$ ), while it was associated with a decreased efficacy of the drug during night-time (10:00 p.m. to 6:00 a.m.): median gastric $\mathrm{pH} 6.8$ (interquartile range: 6.4-6.9) vs $5.4(4.5-6.4), p=0.007$.
Conclusions: In duodenal ulcer patients, the antisecretory effect of ranitidine depends on $H$. pylori. However, the loss of effectiveness during night-time after cure of the infection is less pronounced as the decrease of the $\mathrm{pH}$ response to omeprazole $(20 \mathrm{mg}$ at 9:15 a.m.) during night-time (median $\mathrm{pH}: 6.4$ vs 2.1).

\section{C:08 THE EFFECT OF HELICOBACTER PYLORI INFECTION ON NSAID-RELATED GASTRO-DUODENAL DAMAGE IN THE ELDERLY}

A. Pilotto, G. Leandro ', M. Franceschi, L. Bozzola ${ }^{2}$, M. Rassu, G. Valerio. Dept. of Geriatrics, S. Bortolo Hospital Vicenza, Italy; ' Dept. of Gastroenterology, Castellana Grotte (BA); ${ }^{2}$ Clin. Pathol. Service,

Vicenza, Italy; Microbiology Service, Vicenza, Italy

With the aim to evaluate the role of HP infection on the prevalence and severity of NSAID-related upper G.I. lesions in the elderly we studied endoscopically 154 subjects NSAID-users with upper GI symptoms (62 males, 92 females; mean age: 80 years, range: 67-98). Patients were defined as "NSAID-users" if they took a drug of this class any time in the 7 days prior to endoscopy and by different use patterns they were separated in Occasional Users, Acute Users or Chronic Users. In 128 subjects HP infection was studied by histology ( 2 antral and 2 body gastric biopsies, Giemsa and H\&E stains) and by the rapid urease test. Statistical analysis was performed by means of Student $t$ test for unpaired data and the $\chi^{2}$ test. Results: $127 / 154$ subjects $(82.4 \%)$ presented gastro-duodenal damage: 6 pts (3.9\%) were affected with erosive oesophagitis (OE), 46 pts $(29.9 \%)$ with gastric ulcer (GU), 48 pts (31.1\%) with duodenal ulcer (DU), 5 pts (3.2\%) with both GU and DU and 22 pts (14.3\%) with erosive gastritis (EG). 64/154 pts (41.55\%) were affected with a bleeding lesion. 74/128 pts (57.8\%) resulted HP-positive. HP-positive pts presented a statistically significant higher percentage of GU $(68.4 \%$ vs $31.6 \%, \mathrm{p}<$ $0.0001)$ and DU $(67.4 \%$ vs $32.6 \%, p<0.0001)$ and a lower percentage of oesophagitis (33.3\% vs $66.7 \%, \mathrm{p}<0.05)$ and non gastro-duodenal lesions $(38.1 \%$ vs $61.9 \%, p=0.01)$. No significant differences were found between HP-negative (46\%) and HP-positive (54\%) subjects as regards bleeding lesions. No significant differences were observed as regards NSAID use patterns between HP-positive and HP-negative subjects: respectively occasional users: $55.4 \%$ vs $51.8 \%$, acute users: $12.1 \%$ vs $14.2 \%$, chronic users: $32.4 \%$ vs $35.1 \%$. In conclusion 1) HP infection was associated with higher NSAID-related GU and DU in the elderly; 2) HP infection was not associated with a higher risk of bleeding in elderly NSAID-users.

\section{C:09 INFECTION WITH CagA+ H. PYLORI STRAINS ASSOCIATED WITH HEIGHTENED SERUM PEPSINOGEN C AND LOWER ANC RATIOS}

M. Kudo', M. Asaka ${ }^{1}$, M. Kato ${ }^{1}$, M. Katagiri ${ }^{~}$, K. Nishikawa ${ }^{1}$,

H. Kagaya' ${ }^{\prime}$, M. Sukegawa $^{1}$, H. Takeda ${ }^{1}$, H. Kleanthous ${ }^{2}$, M.J. Blaser ${ }^{3}$

${ }^{1}$ Hokkaido University, Sapporo, Japan; ${ }^{2}$ OraVax, Inc., Cambridge, USA;

${ }^{3}$ Vanderbilt University, Nashville, USA

Aim: Studies in Western populations indicate that infection with $\mathrm{cagA}{ }^{+} \mathrm{H}$. pylori strains is associated with increased levels of acute gastric inflammation and injury. To assess the role of these strains in gastric mucosal injury in the Orient, we examined the relationship between cagA status and pepsinogen (PG) levels in japanese adults (20 to 69 years old) Methods: Sera obtained from 392 asymptomatic adults in Sapporo were examined for IgG evidence of $H$. pylori infection using the HM-CAP ELISA. Serum PG $\mathrm{A}$ and $\mathrm{C}$ were measured by radioimmunoassay (Dinabott). Serum anti-CagA IgG was detected as described (Cancer Research 1995; 55: 2111). Unpaired T-test and Mann-Whitney U-test were used for statistic analysis. Results: 234 (59.7\%) of the adults were $H$. pylori -infected, and of these, $158(67.5 \%)$ were infected with $\mathrm{CagA}^{+}$strains. In persons infected with $\mathrm{CagA}^{+}$strains compared to those with $\mathrm{CagA}^{-}$strains, $\mathrm{PG} \mathrm{A}$ levels were similar, PG $C$ levels were significantly higher $(p<0.001)$, and PG $\mathrm{A} / \mathrm{C}$ ratios were significantly $(\mathrm{p}<0.001)$ lower. Conclusion: Infection with a CagA ${ }^{+}$strain is associated with evidence of enhanced gastric inflammation, suggesting a linkage with gastric cancer in this population.

\begin{tabular}{lllll}
\hline & Mean age & PG A & PG C & PG A/C ratio \\
\hline $\mathrm{HP}^{+} \mathrm{CagA}^{+} \mathrm{n}=158$ & 44.4 & 55.7 & 20.5 & 2.93 \\
$\mathrm{HP}^{+} \mathrm{CagA}^{-} \mathrm{n}=76$ & 44.4 & 54.5 & 13.2 & 4.56 \\
$\mathrm{HP}^{-} \mathrm{n}=158$ & 44.4 & 7.9 & 9.7 & 5.46 \\
\hline
\end{tabular}




\section{C:10 H. PYLORI ERADICATION IMPROVES GLANDULAR ATROPHY IN THE GASTRIC MUCOSA}

K. Kusugami, T. Ando, M. Ohsuga, T. Konagaya, T. Shimizu, K. Kyokane, M. Shinoda, K. Ina, N. Kasuga. Nagoya University Hospital, Nagoya, Japan

Little is known about the effect of $H$. pylori eradication therapy on glandular atrophy and intestinal metaplasia in the gastric mucosa. We analyzed the changes of histology and serum pepsinogen I/II after $H$. pylori eradication therapy. Methods: Eleven patients with duodenal ulcer (DU) and 12 with gastric ulcer (GU) were treated with one week therapy consisting of omeprazole $(40 \mathrm{mg} /$ day $)$, clarithromycin $(600 \mathrm{mg} /$ day $)$ and metronidazole $(1.0 \mathrm{~g} /$ day). $\mathrm{H}$. pylori infection was confirmed by CLO test, $H$. pylori culture, histology and ${ }^{13} \mathrm{C}$-urea breath test. Histological changes were assessed with Sydney system using endoscopic biopsies from the great curvature of the gastric antrum and body. Results: We succeeded in H. pylori eradication in all 23 patients when assessed by $H$. pylori culture, histology, PCR and ${ }^{13} \mathrm{C}$-urea breath test. Ulcer healing was achieved in all cases except one GU patient. The rate of transition to $S_{2}$ ulcer scar (white scar) was $91 \%$ in one month and $100 \%$ in 6 months in DU patients, whereas it was $33 \%$ and $75 \%$, respectively, in GU patients. Histological glandular atrophy improved in 18 of 23 cases (antrum, one month $\mathrm{p}<$ $0.01,6$ months $\mathrm{p}<0.005$; body, one month $\mathrm{p}<0.005,6$ months $\mathrm{p}<$ $0.0005)$. There was a significant increase in the ratio of pepsinogen I/II (before $4.29 \pm 0.31$; one month $6.44 \pm 0.35, \mathrm{p}<0.0005 ; 6$ months 6.23 $\pm 0.32, p<0.0005$ ). However, no significant changes were observed in intestinal metaplasia after eradication therapy. Conclusion: The presen study suggested that successful $H$. pylori eradication therapy may lead to improvement in glandular atrophy of the gastric mucosa.

\section{C:11 EFFECT OF ERADICATION OF HELICOBACTER PYLORI ON GASTRIN, PEPSINOGEN AND GASTRIC EMPTYING OF SOLIDS IN PATIENTS WITH GASTRIC ULCER. A CONTROLLED STUDY}

G. Maconi, M. Lazzaroni, O. Sangaletti, M. Minguzzi, S. Bargiggia, F. Parente, L. Vago ${ }^{1}$, G. Bianchi Porro. ' ${ }^{\prime}$ Gastrointestinal Unit, $L$. Sacco Hospital, Milan, Italy; Department of Pathology, L. Sacco Hospital, Milan, Italy

Aim. The behaviour of basal and meal stimulated gastrin release, pepsinogen levels and gastric emptying of solids was studied in 16 consecutive patients with $\mathrm{H}$. pylori positive, uncomplicated, NSAIDs uncorrelated gastric ulcer (GU) over a follow-up of three months after eradicating therapy.

Patients and methods. Before starting treatment consisting of omeprazole $40 \mathrm{mg}$ a day for 1 month and amoxicillin $1 \mathrm{~g}$ three times daily for 14 days, and 3 months after ulcer healing, each patient underwent a series of functional examinations including basal and meal-stimulated serum gastrin concentration, serum pepsinogen I levels and an evaluation of gastric emptying of solids through serial ultrasonographic measurement of the gastric antrum area.

Results. Double therapy for $\mathrm{Hp}$ resulted in successful eradication in 8 of 16 patients. In Hp eradicated patients the mean ratios of integrated gastrin response to meal [(AUC pg/ml/h): $23428 \pm 5727$ vs $17623 \pm 3993$ ], but not fasting gastrin concentration $[(\mathrm{pg} / \mathrm{ml}) 67.7 \pm 14.4 \mathrm{vs} 59.6 \pm 11.9)]$, fell significantly during the follow-up and serum pepsinogen I levels significantly decreased compared to baseline $[(\mathrm{ng} / \mathrm{l}) 95.0 \pm 27.8$ vs $79.7 \pm 32.3]$ In contrast, fasting and maximal antral area and gastric emptying of solids remained unchanged over time. In the control, not Hp eradicated group, no significant modifications of any of the above mentioned parameters were observed during follow-up.

Conclusion. These results suggest that like duodenal ulcer, in GU patients $\mathrm{Hp}$ eradication also significantly modifies gastrin and pepsinogen I relase in a short follow-up period. In contrast, gastric emptying of solids is not affected at least within a period of 3 months.

\section{C:12 INCREASED HYPERGASTRINAEMIA WITH PROTON PUMP INHIBITION IN HELICOBACTER PYLORI INFECTION}

P. Bampton ${ }^{1}$, J.R. Lambert ${ }^{2}$, P. Midolo ${ }^{2}$, J. Savage ${ }^{3}$, P.J. Prichard ${ }^{4}$ 1 Gastroenterology Department, St. George's Hospital; ${ }^{2}$ Gastroenterology Research Group, Frankston Mornington Peninsula Hospital;

${ }^{3}$ Gastroenterology Unit, Flinders Medical; ${ }^{4}$ Department of Gastroenterology and Hepatology, Princess Alexandra Hospital

Elevations of fasting serum gastrin occurs in most subjects treated with proton pump inhibitors. The aim of this study was to assess the role of $H$. pylori in these changes. Methods: One hundred and twenty five subjects (59 $H$. pylori infected, $66 \mathrm{H}$. pylori non infected) treated with lansoprazole 30 $\mathrm{mg}$ daily had fasting venous blood collected before and after 56 days ther- apy, for reflux oesophagitis. Blood samples were also collected after nine and twelve months maintenance therapy with either lansoprazole 15 or 30 $\mathrm{mg}$, or omeprazole $20 \mathrm{mg}$ daily in 72 subjects ( $38 \mathrm{H}$. pylori infected, $34 \mathrm{H}$. pylori non-infected). $H$. pylori status was determined by IgG EIA (Amrad). Fasting serum gastrin levels were performed by a specific RIA. Results: There was no significant difference in pre-treatment fasting serum gastrin levels between $H$. pylori infected $(69 \pm 4 \mathrm{pg} / \mathrm{ml})$ and non-infected subjects $(69 \pm 9 \mathrm{pg} / \mathrm{ml})$. Both $H$. pylori infected and non-infected groups had a significant elevation in serum gastrin after 56 days of lansoprazole therapy (to $130 \pm 9$ and $97 \pm 9 \mathrm{pg} / \mathrm{ml}$ respectively). This elevation of fasting serum gastrin was significantly higher for $H$. pylori infected subjects ( $\mathrm{p}<$ 0.05 ). During the maintenance phase a further rise in fasting serum gastrin was seen in all three treatment groups. Again, this rise was significantly greater in patients who had concurrent $H$. pylori infection. There was no difference between the omeprazole $20 \mathrm{mg}(\mathrm{n}=24)$ and lansoprazole 30 $\mathrm{mg}(\mathrm{n}=27)$ treated groups. Conclusions: (1) The use of proton pump inhibition in reflux oesophagitis is associated with a significant increase in fasting serum gastrin. (2) This increase is significantly greater in patients who are infected with $H$. pylori. (3) Comparable doses of omeprazole and lansoprazole have similar effects on fasting serum gastrin in the infected and non-infected subject and (4) the fasting serum gastrin levels continue to rise after $\mathbf{5 6}$ days of therapy. This phenomenon may be due to the associated inflammation sensitising the $\mathrm{G}$ cell to hypochlorhydria, or it may be secondary to augmented acid suppression from proton pump inhibition in the presence of $H$. pylori infection.

\section{C:13 H. PYLORI AND AGE DECREASE MUCOSAL HYDROPHOBICITY}

A. Hackelsberger, U. Platzer, M. Nilius, J.E. Dominguez-Munoz, T. Günther ${ }^{1}$, E. Bayerdörffer, P. Malfertheiner. Dept. of Gastroenterology, Univ. of Magdeburg, Germany; ${ }^{1}$ Dept. of Pathology, Univ. of Magdeburg, Germany

Background: Reduced mucosal surface hydrophobicity is measured by goniometry in chronic H. pylori (HP)-gastritis (Spychal RT, 1990).

Aim: To investigate surface hydrophobicity in relation to age, mucosal histology and gastric topography in HP+ve and HP-ve subjects.

Patients \& Methods: We excluded pats. with peptic ulcer disease, NSAID, steroids, regular alcohol intake, smoking, antisecretory - and HP eradication treatment. Endoscopic biopsies of the gastric antrum, corpus and cardia region were obtained in 120 patients for histology (five parametric grading according to the Sydney System) and immediate contact angle measurement using a Rame-Hart 100/00 goniometer. In addition a biopsy urease test, culture and a Westernblot serology (BAG-Pylori-Blot) were performed to assess the HP-status most accurately. Three age groups were formed for Hp+ve and HP-ve subjects: I) $</=40$ ys, II) $>40 /<70$ ys, III) $>70$ ys. Multiple Cox regression analysis (SPSS Win 6.1) was performed to detect the variables independently associated with hydrophobicity.

Results:

Contact angle measurement $\left(^{\circ}\right)$

\begin{tabular}{|c|c|c|c|c|c|c|}
\hline \multirow{2}{*}{$\begin{array}{l}\text { Age group } \\
\mathrm{n}=\mathrm{HP}-\mathrm{ve} /+\mathrm{ve}\end{array}$} & \multicolumn{2}{|l|}{ Antrum } & \multicolumn{2}{|l|}{ Corpus } & \multicolumn{2}{|l|}{ Cardia } \\
\hline & HP-ve & $\mathrm{HP}+\mathrm{ve}$ & HP-ve & HP+ve & HP-ve & HP+ve \\
\hline $\begin{array}{l}\text { I. } n=27 / 11 \\
\text { II. } n=24 / 28 \\
\text { III. } n=10 / 20\end{array}$ & $\begin{array}{l}71.93^{\circ} \\
69.53^{\circ} \\
63.88^{\circ}\end{array}$ & $\begin{array}{l}65.02^{\circ} \\
64.08^{\circ} \\
61.03^{\circ}\end{array}$ & $\begin{array}{l}69.96^{\circ} \\
68.89^{\circ} \\
64.25^{\circ}\end{array}$ & $\begin{array}{l}62.13^{\circ} \\
61.81^{\circ} \\
59.88^{\circ}\end{array}$ & $\begin{array}{l}70.04^{\circ} \\
68.71^{\circ} \\
62.94^{\circ}\end{array}$ & $\begin{array}{l}63.75^{\circ} \\
63.11^{\circ} \\
60.58^{\circ}\end{array}$ \\
\hline
\end{tabular}

Regression analysis $(\mathrm{OR}=$ odds ratio)

\begin{tabular}{llllll}
\hline & \multicolumn{2}{l}{ HP-infection } & & \multicolumn{2}{l}{ Patient age } \\
\cline { 2 - 3 } \cline { 5 - 6 } & OR & $\mathrm{p}$ & & OR & $\mathrm{P}$ \\
\hline Antrum & 2.14 & 0.0008 & & 1.02 & 0.008 \\
Corpus & 3.52 & 0.0001 & & 1.01 & 0.035 \\
Cardia & 2.62 & 0.0001 & & 1.02 & 0.008 \\
\hline
\end{tabular}

H. pylori status and age are the only two independent variables that correlate significantly with hydrophobicity of gastric mucosa. Neither the histological scores, nor biopsy topography showed a correlation.

Conclusion: A highly significant decrease of gastric hydrophobicity with HP-gastritis is confirmed. In HP-ve subjects aging alone strongly decreases gastric hydrophobicity. The increased susceptibility to mucosal damage in the elderly may add to other risks (e.g. NSAIDs).

\section{C:14 GASTRIC ACID SECRETION HAS INCREASED IN JAPAN IN THE LAST 20 YEARS}

T. Kamada, K. Haruma, K. Kiyohira, M. Mihara, T. Goto, M. Yoshihara, H. Mieno, K. Sumii, M. Inoue, G. Kajiyama. First Dept. of Internal Medicine, Hiroshima University School of Medicine, Hiroshima, Japan

Recently gastric carcinoma is declining and duodenal ulcer is increasing in Japan. The pathogenesis of duodenal ulcer is regarded to a high acid 
secretion, however at present there is no available information concerning the trend for gastric acid secretion.

The Aim of this study is to investigate the trend for gastric acid secretion in Japan between 1975 and 1995.

Methods: Gastric acid secretion in $\mathrm{H}$. pylori-negative young male volunteers was compared between 1975 and 1995. H. pylori infection was evaluated by Giemsa stain and/or serum $\mathrm{H}$. pylori antibody (IgG). The analysis included measurement of basal acid output (BAO) and maximum acid output (MAO) stimulated by tetragastrin $(4 \mu \mathrm{g} / \mathrm{kg}$ im).

Results: (Mean $\left.\pm \mathrm{SE},{ }^{*} \mathrm{p}<0.05,{ }^{* *} \mathrm{p}<0.01\right)$

\begin{tabular}{lcc}
\hline & $1975(\mathrm{n}=11)$ & $1995(\mathrm{n}=11)$ \\
\hline Mean age & 22.7 & 21.5 \\
BAO (mEq/h) & $2.31 \pm 0.84$ & $4.01 \pm 0.74^{*}$ \\
MAO $(\mathrm{mEq} / \mathrm{h})$ & $13.63 \pm 3.33$ & $21.86 \pm 2.33^{* *}$ \\
BAO/BW $(\mathrm{mEq} / \mathrm{h} \cdot \mathrm{kg})$ & $0.04 \pm 0.01$ & $0.06 \pm 0.01$ \\
MAO/BW $(\mathrm{mEq} / \mathrm{h} \cdot \mathrm{kg})$ & $0.23 \pm 0.05$ & $0.35 \pm 0.04^{*}$ \\
\hline
\end{tabular}

BW: Body Weight.

Conclusion: Our data demonstrates that there is a trend for increase of gastric acid secretion in Japan. This increase of gastric acid secretion might be linked to the increasing incidence of duodenal ulcer in this country and the westernization of lifestyle.

\section{C:15 HELICOBACTER PYLORI UNDERMINES GASTRIC INTEGRITY BY ACUTELY REDUCING MUCUS SECRETION AND BLOOD FLOW IN RATS}

C. Atuma, L. Engstrand ' , L. Holm. Dept. of Physiology and Med. Biophysics, Uppsala University, Uppsala, Sweden; ${ }^{1}$ Depts. of Clin. Microbiology and Cancerepidemiology, Uppsala University, Uppsala, Sweden

Introduction: We have studied the effects of water extracts produced from Helicobacter pylori (Hp) on gastric mucosal defence mechanisms, in particular blood flow and mucus secretion, in inactin anaesthetized rats.

Method: Three different isolates of Hp were used: 88-23 and A5, both wildtype, producing the vacuolating cytotoxin (VacA) and A5VacA, a knock-out mutant of A5, with no production of VacA. The luminal surface of the gastric corporal mucosa was visualized for intravital microscopy. Water extracts from each isolate were applied for 40 minutes. This was done after removing as much as possible of the mucus layer by suction with a thin cannula connected to a vacuum pump. Mucus thickness was measured using a microelectrode and blood flow by using the laser-Doppler flowmetry technique.

Results: The 28 rats used for mucus measurements had a mean mucus thickness of $239 \pm 21 \mu \mathrm{m}$. A firm layer, $97 \pm 5 \mu \mathrm{m}$ thick, remained after mucus removal. In control animals a fast mucus growth rate was measured directly after mucus removal, slowly declining with time. All animals treated with the bacterial extracts had an initial growth rate just below that in the control animals but later, had a significantly $(\mathrm{p}<0.05)$ lower growth rate. Blood flow was significantly $(P<0.05)$ reduced by the extract from all three Hp isolates; $88-23$ by $15 \pm 7 \%(n=7)$, A5 by $17 \pm 3 \%(n=5)$ and A5VacA by $16 \pm 5 \%(n=5)$.

Conclusion: The results suggest that $\mathrm{Hp}$ produces a factor or a combination of factors that reduce mucus secretion and mucosal blood flow, in an acute phase of the infection. However, VacA does not seem to be responsible for these effects.

\section{C:16 HELICOBACTER INHIBITS DIRECTLY ACID SECRETION BY H3 RECEPTOR MEDIATOR PATHWAY}

A. Alchepo, I. Sobhani, L. Moizo, J.P. Laigneau, M. Mignon, A. Labigne, M.J.M. Lewin, A. Bado. INSERM U10, Hôpital Bichat \& Institut Pasteur, Paris-France

Helicobacter modifies gastric acid secretion interfering with gastrin, somatostatin and histamine. It increases $\mathrm{N}$-methylhistamine a known $\mathrm{H} 3$ selective receptor agoniste. Previous study from us and others have shown that activation of $\mathrm{H} 3$ receptor reduces stimulated gastric acid secretion. The aim of the present study was to investigate $\mathrm{H} 3$ receptor pathway in vivo in cat before and after eradication. Materials. Six adult cats (Iffa Credo) provided with a fistula in the stomach were examined for the presence of Helicobacter using biopsies submitted to CLO test, histology, culture and/or PCR analysis. Meal-, histamine (20-160 $\mu \mathrm{g} / \mathrm{kg} / \mathrm{hr})$ - and gastrin (G5 1-32 or $\mathrm{G} 170.5 \mu \mathrm{g} / \mathrm{kg} / \mathrm{hr}$ )-stimulated $\mathrm{H}+$ outputs were analysed after 18 $\mathrm{hr}$ fasting before and 5 weeks after Helicobacter eradication (15 days PPI +2 antibiotics therapy). The effect of thioperamide, $R \alpha$ methyhistamine (H3 receptor antagoniste) on the G17-stimulated acid secretion and serum gastrin (RIA) level $(4 \times 15 \mathrm{~min})$ in response to meal were analysed before and after eradication. Results: Before eradication histology did not show mucosal infiltration. Before eradication CLO test was positive and $\mathrm{H}$. felis $(n=4)$ and Heilmanni $(n=2)$ were characterized; after eradication no bacterium was found and CLO tests were negative. Meal-stimulated gastrin level remained unchanged by eradication therapy. Acid secretion increased $(40 \%)$ significantly $(\mathrm{p}<0.01)$ after eradication in a dose-dependent manner in response to pentagastrin or histamine and to $\mathrm{G} 17$ (i.e. $1580+300 \mu \mathrm{Eq} / 15$ min vs $940+190 \mu \mathrm{Eq} / 15 \mathrm{~min}$ ). The level of gastric acid output under "thiopermaide + G17" before eradication was similar to that observed under "G17 alone" after eradication. Conclusion. These results demonstrate that Helicobacter but no inflammatory cells inhibits acid secretion in cat. Since thioperamide reversed this Helicobacter inhibitory effect, we suggest that Helicobacter inhibits acid secretion via an $\mathrm{H} 3$ receptor mechanisme.

\section{C:17 EFFECT OF HELICOBACTER PYLORI ACID INHIBITORY FACTOR 1 (AIF-1) ON H+/K' -ATPASE ACTIVITY IN VITRO}

N. Masubuchi, P.J. Goddard, J.S. Hoffman, A.V. Kane ${ }^{1}$, D.R. Cave. Division of Gastroenterology, St. Elizabeth's Medical Center of Boston, Boston MA, USA; ${ }^{1}$ New England Medical Center, Boston MA, USA

AIF-1 is a novel $46 \mathrm{kD}$ protein expressed by $H$. pylori that inhibits acid secretion in isolated gastric glands. The mechanism of action of AIF-1 is not known. We tested the hypothesis that AIF-1 acutely inhibits acid secretion from parietal cells by inhibiting $\mathrm{Mg}^{+2}$-dependent $\mathrm{H}^{+} / \mathrm{K}^{+}$-ATPase activity. AIF-1 was isolated by preparing $\mathrm{a}>10 \mathrm{kD}$ fraction of the bacterial lysate by ultrafiltration under $100 \% \mathrm{~N}_{2}$. The presence of AIF-1 in this phosphatefree ultrafiltrate was confirmed by ELISA. Biological activity of AIF-1 was confirmed by its ability to inhibit the accumulation of ${ }^{14} \mathrm{C}$-aminopyrine into histamine and isobutylmethylxanthine stimulated isolated rabbit gastric glands. Membrane vesicles containing $\mathrm{H}^{+} / \mathrm{K}^{+}$-ATPase were prepared by differential centrifugation of disrupted isolated rabbit gastric glands. Parietal cell membranes were incubated in the presence or absence of increasing concentrations of the ultrafiltrate for a 10 -minute period at $37^{\circ} \mathrm{C}$. Enzyme activity was assessed spectrophotometrically by measuring the production of inorganic $\mathrm{PO}_{4}^{-3}$ from the hydrolysis of ATP. $\mathrm{K}^{+}$-stimulated, $\mathrm{Mg}^{+2}$-dependent ATPase activity in the absence of ultrafiltrate was 20.2 $\pm 3.4\left(\mu \mathrm{mole} \mathrm{PO}_{4}^{-3} / \mathrm{mg}\right.$ protein $/ \mathrm{hr}$ ). The $H$. pylori ultrafiltrate reduced the hydrolysis of ATP (maximum inhibition $29.2 \%$ of control values) but this decrease was not statistically significant $(p>0.05)$. There was no evidence for a dose-dependent inhibition of enzyme activity over the concentration range of $H$. pylori ultrafiltrate tested $(0.05-50 \mu \mathrm{g} / \mathrm{ml}$ total protein).

Conclusion: AIF-1 does not dose-dependently inhibit $\mathrm{H}^{+} / \mathrm{K}^{+}$-ATPase activity in isolated parietal cell membranes in vitro.

\section{C:18 MOLECULAR MIMICRY OF H. PYLORI BY EXPRESSION OF LEWIS TYPE II AND TYPE I ANTIGENS}

H.P. Wirth, M. Yang, M. Karita, M.J. Blaser. Dept. of Medicine, Vanderbilt University School of Medicine, Nashville, TN 37232-2605

Aspinall et al. showed that the lipopolysaccharide of $H$. pylori can possess Lewis ${ }^{x}\left(\operatorname{Le}^{x}\right)$ or Le ${ }^{y}$ antigens. Our aim was to quantitate Le expression and to study the relation of genotypic and clinical characteristics of $H$. pylor isolates to Le expression.

Methods: Le antigens of $H$. pylori whole cells were determined by ELISA using monoclonal antibodies to $\mathrm{Le}^{\mathrm{a}}, \mathrm{Le}^{\mathrm{b}}, \mathrm{Le}^{\mathrm{x}}$, sialyl-Le $\mathrm{L}^{\mathrm{x}}$, or $\mathrm{Le}^{\mathrm{y}} . E$ coli $\mathrm{HB} 101$ cells served as a control. $H$. pylori isolates from 19 countries have been examined. The presence of cagA was determined by PCR and colony hybridization. 45 isolates had been previously characterized for vacA subtype. Isogenic mutants of $H$. pylori CPY3401 were obtained by interruption of the cagA $\left(3401 \mathrm{~A}^{-}\right)$, picB $\left(3401 \mathrm{~B}^{-}\right)$, or ureA $\left(3401 \mathrm{U}^{-}\right)$ genes.

Results: $\mathrm{Le}^{\mathrm{x}} / \mathrm{Le}^{\mathrm{y}}$ expression was stable and independent of the growth medium and age of $H$. pylori cells. Of $94 \mathrm{H}$. pylori isolates, $74 \%$ expressed $\mathrm{Le}^{\mathrm{y}}, 60 \% \mathrm{Le}^{\mathrm{x}}, 13 \% \mathrm{Le}^{\mathrm{b}}, 3 \% \mathrm{Le}^{\mathrm{a}}$, and $2 \%$ sialyl-Le ${ }^{\mathrm{x}} ; 11 \%$ were negative for all determinants. $57 \%$ of the isolates expressed $\geq 2$ distinct Le antigens. $\operatorname{cagA}^{+}$compared with cagA ${ }^{-}$isolates expressed $\mathrm{Le}^{\mathrm{x}}(72 \%$ vs $22 \%)$ and $\mathrm{Le}^{y}(87 \%$ vs $35 \%)$ significantly $(\mathrm{p}<0.001)$ more often. In parallel, the mean level of $\mathrm{Le}^{\mathrm{x}}$ and $\mathrm{Le}^{\mathrm{y}}$ expression was higher $(\mathrm{p}<0.01)$ in $c a g A^{+}$ than cag $A^{-}$isolates. $\mathrm{Le}^{\mathrm{x}}$ and/or $\mathrm{Le}^{\mathrm{y}}$ expression were positively associated with both vacA s1 signal sequence $(\mathrm{p}<0.01)$ and $\mathrm{m} 1$ mid-region type $(\mathrm{p}=$ $0.013)$ and with ulcer disease $(p<0.01)$.

Mutant strain 3401A- had diminished (47\%) expression of $\mathrm{Le}^{\mathrm{y}}(533 \pm$ 121 ODU) compared to cagA ${ }^{+}$wild type strain 3401 (1136 \pm 113 ODU, $p$ $<0.01$ ) and to mutants $3401 \mathrm{~B}^{-}$and $3401 \mathrm{U}^{-}$. Expression of $\mathrm{Le}^{\mathrm{x}}$ for wild type 3401 and the 3 isogenic mutants was similar.

Conclusions: Most H. pylori isolates stably expressed one or more Le determinants in vitro. Le type II $\left(\mathrm{Le}^{\mathrm{x}}, \mathrm{Le}^{\mathrm{y}}\right)$ predominated over type I ( $\mathrm{Le}^{\mathrm{a}}$, $\mathrm{Le}^{\mathrm{b}}$ ) determinants. $\mathrm{Le}^{\mathrm{x}} / \mathrm{Le}^{\mathrm{y}}$-positive isolates were predominantly $\operatorname{cagA}^{+}$ and possessed vacA $\mathrm{s} 1$ signal sequence and $\mathrm{m} 1 \mathrm{mid}$-region types. Enhanced expression of host antigens by $\mathrm{cagA}^{+}$isolates could counterbalance their proinflammatory activities and thereby facilitate persistent infection. 


\section{C:19 INTERLEUKIN-8 ACTIVITY INDUCED IN MKN45 CELLS AFTER INCUBATION WITH H. PYLORI: COMPARISON WITH ORGAN CULTURES OF GASTRIC ANTRAL MUCOSA}

M. Ohsuga, T. Ando, T. Konagaya, T. Shimizu, K. Kyokane, M. Shinoda, T. Yamaguchi, A. Imada, K. Ina, M. Sakakibara, N. Kasuga, K. Kusugami. Nagoya University Hospital, Nagoya, Japan

In patients with $H$. pylori infection, elevation of gastric mucosal interleukin8 (IL-8) activity has been demonstrated. However, little is known about the mechanisms involved in elevated IL-8 activity in $H$. pylori infection. We measured the levels of $\mathbb{I L}-8$ induced in the gastric epithelial cell line, MKN45 cells after incubation with $H$. pylori isolated from patients with gastroduodenal disease, and we compared them with IL-8 activity detected in the organ cultures of antral mucosal biopsies. Methods: H. pylori was isolated from the endoscopic biopsies in 7 patients with duodenal ulcer, 7 with gastric ulcer, 4 with gastritis, and 2 with normal mucosa. MKN45 cells were incubated with $H$. pylori (cell/bacteria; $1 / 100$ ) for $24 \mathrm{hrs}$. The antral mucosal biopsy tissue was cultured on a culture insert over the well containing the medium for $24 \mathrm{hrs}$. The levels of IL-8 in the culture supernatant were measured by the ELISA kit (Toray-Fuji, Tokyo, Japan) Results: There was a weak correlation between the levels of IL-8 induced in MKN45 cells $(32.1-936.3 \mathrm{pg} / \mathrm{ml})$ and those detected in the organ cultures of biopsy tissue $(2.5-54.3 \mathrm{ng} / \mathrm{mg}$ biopsy protein) in individual patients. However, considerable discrepancy was observed between these two assays. Conclusion: Host factors as well as strain diversity of $H$. pylori are important as the mechanisms involved in elevated mucosal IL-8 activity in $H$. pylori infection.

\section{C:20 INTERLEUKIN-6 AND -8 GENE EXPRESSION OF HUMAN GASTRIC EPITHELIAL CELLS INFECTED WITH HELICOBACTER PYLORI}

N. Nakajima ${ }^{1}$, H. Kuwayama ${ }^{2}$, Y. Ito ${ }^{1}$, A. Iwasaki ${ }^{1}$, Y. Arakawa ${ }^{1}$. ${ }^{1}$ Department of Medicine, Nihon University School of Medicine, Tokyo, Japan; ${ }^{2}$ Department of Medicine, Tokyo Women's Medical College, Tokyo, Japan

Gastric infection with Helicobacter pylori (H. pylori) activates a mucosa inflammatory response by mononuclear cells and neutrophils that includes expression of cytokines interleukin- 6 and -8. The exact role of IL- 6 and -8 in inflammatory response is not known, but are thought to be to serve as a potent inflammatory mediator attracting and activating polymorphonuclear leukocytes, neutrophils in particular. Since $\mathrm{H}$. pylori appears to contact only the surface of the gastric epithelium, the secretion of IL- 6 or -8 by the gastric epithelium as a result of the interaction between the bacterium and the epithelium may be important in initiating and regulating inflammatory and immune processes in response to this bacterium. In this study, we analyzed IL- 6 and -8 gene expression by reverse transcription-PCR of human gastric epithelial cells, Kato-III, to $\mathrm{H}$. pylori infection with special reference to neutrophil modification. Human IL-6 and -8 specific mRNA was detected when Kato-III cells were incubated with neutrophils or $\mathrm{H}$. pylori. H. pylori itself did not express II -6 and -8 mRNA, whereas Kato-III cells and neutrophils showed expression of these 2 cytokine mRNAs. IL-8 mRNA expression by Kato-III cells was further enhanced when they were co-incubated with both $\mathrm{H}$. pylori and neutrophils compared to those with neutrophils only. We conclude that human gastric epithelial cells Kato-III expresses IL- 6 and -8 mRNA which can be further enhanced by neutrophils. These results indicate that neutrophil may upregulate IL-8 mRNA expression in H. pylori-infected gastric epithelial cells. 2C:21 H. PYLORI INDUCES A DECREASE IN TRANSEPITHELIAL
ELECTRICAL RESISTANCE (TER) IN EPITHELIAL MONOLAYERS

Ana M. Terrés ${ }^{1}$, J.M. Pajares ${ }^{1}$, A. Murphy ${ }^{2}$, H. Windle ${ }^{2}$, A. Baird ${ }^{3}$, D. Kelleher ${ }^{2} .{ }^{1}$ Gastroenterol. Dept, Hospt. de la Princesa, UAM, Madrid Spain; ${ }^{2}$ Department of Clinical Medicine, Trinity College Dublin, Ireland; ${ }^{3}$ Department of Pharmacology, University College Dublin, Ireland

H. pylori (HP) infection is directly related to the development of gastritis and duodenal ulcer but the trigger mechanism for those process is currently unknown. The aim of our study was to analyse the influence of HP on barrier function of gastrointestinal epithelium. In order to asses this we measured the effects of HP on TER of the colonic epithelial cell line T84. Material and Methods: The epithelial cell line T84, grown on permeable filter supports until reaching stable TER values, was exposed to a range of HP stimuli: sonicated HP of two reference strains NCTC11637 (VacA-ve) and NCTC11638 (VacA+ve); killed whole bacteria of both strains and water soluble surface HP proteins. The protein synthesis inhibitor cycloheximide and the protein tyrosine kinase inhibitor herbimycin were also added in some cases to determine the molecular mechanisms of the process. After stimulation, TER was monitored at regular time intervals up to $48 \mathrm{~h}$ and $E$. coli was used as a control. Data were statistically analysed by Student " $t$ " Test. Results: Sonicated HP non cytotoxic strain produced a reduction of TER up to a $47.5 \pm 9 \%$ of the pretreatment value $(\mathrm{p}=0.003, \mathrm{n}=7)$ after $2 \mathrm{~h}$ of exposure, which recovered to the initial pretreatment value after 24 h. This process was not affected by herbimycin but the TER recovery after $2 \mathrm{~h}$ was inhibited by cycloheximide. Sonicated VacA $+\mathrm{HP}$ cytotoxic strain produced similar effects at $2 \mathrm{~h}$ of exposure but the following recovery does not take place and TER falls further to a level of $20 \%$ of the pretreatment value after $24 \mathrm{~h}$ of exposure. Whole bacteria and water soluble surface HP proteins fail to mimic any of these effects. Conclusion: Sonicates from both HP cytotoxic and non cytotoxic strains trigger a decrease in TER at 2 $h$ of exposure to T84 monolayers by a mechanism independent of protein synthesis although the subsequent recovery in the non cytotoxic strain case is protein synthesis dependent. However the VacA+ strain induces irreversible cell damage. These data suggest that infection with non VacAt strains of HP may produce transient changes in barrier function potentially permissive to antigen trafficking across the epithelial barrier. 